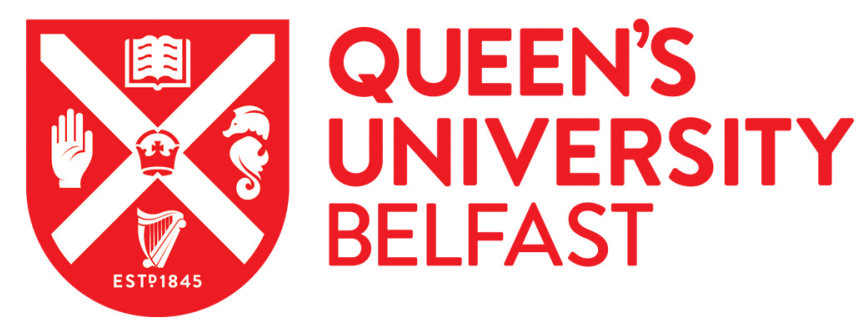

\title{
From Complementary to Competitive: The London and UK Provincial Stock Markets
}

Turner, J., Campbell, G., \& Rogers, M. (2020). From Complementary to Competitive: The London and UK Provincial Stock Markets. The Journal of Economic History, 80(2), 501-530.

https://doi.org/10.1017/S0022050720000194

\section{Published in:}

The Journal of Economic History

\section{Document Version:}

Peer reviewed version

\section{Queen's University Belfast - Research Portal:}

Link to publication record in Queen's University Belfast Research Portal

\section{Publisher rights}

Copyright 2019 Cambridge University Press. This work is made available online in accordance with the publisher's policies. Please refer to any applicable terms of use of the publisher.

\section{General rights}

Copyright for the publications made accessible via the Queen's University Belfast Research Portal is retained by the author(s) and / or other copyright owners and it is a condition of accessing these publications that users recognise and abide by the legal requirements associated with these rights.

Take down policy

The Research Portal is Queen's institutional repository that provides access to Queen's research output. Every effort has been made to ensure that content in the Research Portal does not infringe any person's rights, or applicable UK laws. If you discover content in the Research Portal that you believe breaches copyright or violates any law, please contact openaccess@qub.ac.uk. 


\title{
From Complementary to Competitive: The London and UK Provincial Stock Markets
}

\author{
Gareth Campbell (Queen's University Belfast), Meeghan Rogers (State University of New \\ York) and John D. Turner (Queen's University Belfast)
}

\begin{abstract}
For many decades there were stock exchanges operating in provincial cities across Britain. We analyze why companies listed on these markets, and how this changed over time. We find that the provincial exchanges had traditionally been complementary to London, providing a trading venue for smaller regional companies. However, they gradually lost their uniqueness, and were increasingly competing with London by listing similar stocks. Much of this change can be explained by shifts in industrial composition leading to more companies being headquartered and listed in the capital, and many of the remaining regional firms cross-listing in London to achieve certification.
\end{abstract}

JEL codes: G10; N23; N24

Keywords: Stock markets, market specialization, market integration

Disclosure: Following the release of an earlier working paper version of this research, the authors have been involved in researching the feasibility of launching a new regional stock exchange in Northern Ireland. 


\section{Introduction}

Recent years have witnessed considerable changes in the structure of financial markets around the world. There has been an increasing number of platforms, such as 'dark pools', but these tend to be run by a small number of major multinational exchanges after a wave of amalgamations. ${ }^{1}$ There has also been renewed interest in the development of regional stock exchanges. ${ }^{2}$ This has led to interesting parallels with the past. Historically, there were often many stock markets in a single country, based in provincial towns and cities, but there was then a move towards consolidation. Why did this change take place? Why did financial capitalism in various industrial economies often see the development, initially, of many regional exchanges? Why was there then a shift towards centralization?

In this paper, we examine the London and provincial stock markets of the United Kingdom. We focus our analysis on data from the Investor's Monthly Manual, which allows us to estimate how many companies were chiefly traded on the London Stock Exchange and the provincial markets from 1869 to 1929 . We explore which firm-specific factors were associated with a provincial listing. We bring these factors together into a multinomial logit analysis to explain why some companies were solely traded on the provincial markets, or cross-listed on both London and the provincial markets, rather than just being traded on London. We then use our data to analyze exchange characteristics, by assessing how listing strategy was related to governance requirements and liquidity.

We find that the provincial stock exchanges were important venues for regional companies. Smaller firms were more likely to be traded only on the provincial markets, but larger companies also tended to cross-list in London. The provincial markets offered superior

\footnotetext{
${ }^{1}$ The Economist, February 27, 2016, 'Stocks Exchanged'.

${ }^{2}$ Financial Times, 'A Scottish stock exchange: an idea whose time has come?', July 5, 2019. (https://amp.ft.com/content/672248f6-9f02-11e9-b8ce-8b459ed04726).
} 
liquidity for most of the period, but were similar to London in terms of governance requirements.

However, over time the uniqueness of the provincial markets declined. The proportion of publicly traded companies headquartered outside of London fell substantially between the 1860s and 1920s. This was at least partially driven by industry shifts and merger waves. Companies still based in the provinces may also have been increasingly attracted by a crosslisting in London, following the large blue-chip firms which had already adopted this approach. The expansion and formalization of the junior market in London made it easier for other companies to trade there. The advantages in terms of liquidity which the provincial markets had enjoyed also disappeared. As time progressed, the proportion of companies which were solely traded on the provincial exchanges declined considerably.

This may lead to the question as to why the provincial markets, in the later period, did not try to specialize in new areas in an attempt to maintain their differentiated character. However, this would have been easier to attempt than to achieve. The expertise which was developed in a particular set of securities was quite specific. For example, Lavington (1921, p.223) suggested that the London Stock Exchange could be "more conveniently regarded as a group of markets; for it is subdivided into groups of jobbers, each group specializing in a comparatively narrow range of securities".

The provincial markets had historically specialized in companies which operated locally because they had access to local information. Indirectly, this may also have led to some industry expertise, when there were regional concentrations of particular industries. If a market gained a first mover advantage, it could then be built on and extended by networking effects, with traders tending to use that exchange for trading in those types of securities. However, with newly established companies often being headquartered in London, it made it difficult for the provincial markets to develop in new areas. 
There may be some resonance between what happened to the provincial markets in Britain and the regional markets of the United States. In both countries, regional exchanges initially developed by focusing on differentiated, often local, securities. O'Sullivan (2007) has documented the number of shares trading on the various stock exchanges in the United States until 1930, and has noted that the development of some markets, such as the Chicago Stock Exchange, was largely driven by listings of local companies. White (2013) suggests that competitors to the NYSE thrived when they accommodated new industries which were risky and unfamiliar. Brown et al. (2008) find that the bid-ask spreads of the Boston Stock Exchange in the 1880 s were not affected by the competition between the New York Stock Exchange (NYSE) and Consolidated Stock Exchange. This was probably because it was listing different stocks at that time compared to the New York markets.

Arnold et al. (1999) have noted that in the United States the regional markets eventually shifted from mainly hosting local companies, to mainly listing securities which were also traded on the NYSE, and there was subsequently a series of amalgamations between the exchanges. Their focus is on these mergers, so they do not provide detailed analysis as to why the regional markets rose and fell in importance, but they do suggest that improved communication links and changes in securities regulation may have been important.

Similar themes emerge in other countries as well. Hautcoeur and Riva (2012) show that two exchanges in Paris, the Parquet and Coulisse, specialized in different investors and services and were complementary to each other. Burhop and Lehmann-Hasemeyer (2016) find that listing decisions in Germany, between 1897 and 1913, were heavily influenced by the location of the companies, suggesting that each market had some unique constituents.

This paper also contributes to the literature on the role of capital markets in the financing of British companies in the Victorian and Edwardian eras. A commonly held view is that the London Stock Exchange channeled too much capital to colonial or overseas 
companies at the expense of indigenous British industry (for a debate on this issue, and on whether investors acted rationally, see Edelstein, 1982; Pollard, 1985; Kennedy, 1987; Goetzmann and Ukhov, 2006; Chabot and Kurz, 2010; Grossman, 2015). ${ }^{3}$ By shedding light on the important role played by provincial stock exchanges, this paper provides a corrective to this allegation against UK capital markets. Although the raising of capital was not done directly through the exchanges, by providing a venue for the secondary trading of their shares the provincial markets likely made it easier for domestic companies to attract investment.

\section{Sources and Data}

To examine the number of securities listed on provincial markets, we begin by considering the official stock exchange lists which have survived. There are occasional lists available for Liverpool which allow us to observe some of the early trends in the markets. From 1887 onward, the price lists of the Manchester Stock Exchange are available. However, there are several disadvantages to using these records. First, they focus on only one market, so we cannot observe trends across the various regions of the UK. Second, the official lists include many companies which were just nominally listed on these markets, but may have been mainly traded elsewhere.

For these reasons, we focus most of our analysis on data from the Investor's Monthly Manual (IMM), which is available for the period between 1869 and 1929, most of which has been inputted by the Yale International Center for Finance. ${ }^{4}$ The IMM was a monthly investor periodical which reported on market conditions and provided in-depth details on individual securities such as prices, dividends, and the number of shares issued. From the perspective of

\footnotetext{
3 This view was first officially expressed in the Macmillan Report of 1931 (House of Commons, Report of Committee on Finance and Industry).

${ }^{4}$ Data available at http://som.yale.edu/faculty-research/our-centers-initiatives/international-center-

finance/data/historical-financial-research-data/london-stock-exchange.
} 
this paper, the principal advantage of the IMM was that the December issue reported which stock exchanges each company was 'chiefly traded on' ${ }^{5}$. We focus on companies (which could have issued ordinary equity, preference shares, or corporate bonds), rather than government bonds or city loans.

Given its reporting of where companies were 'chiefly traded', the IMM did not report every market on which a company was listed. Companies may have been listed on an exchange, but because of thin trading they were not covered by the IMM. It is also possible that editorial choices may have influenced which companies the IMM reported on, which may mean that our sample is focused on those securities that investors were most interested in and likely to trade. These considerations mean that our results understate the number of firms which were listed on each market, and there may be a tendency towards including larger, more liquid, securities. Nevertheless, this has its own advantages, as it allows a focus on where the thousands of the most commonly traded assets were actively traded, rather than looking at how many securities each exchange nominally listed.

The chiefly traded market information has been input by the Yale ICF for most companies, but was not included for railways, banks or insurance firms. We have manually input this data for these industries, focusing on the companies listed at the end of each decade. For intervening years, and when the IMM did not explicitly report the market for a particular year, we have assumed that the market reported in the IMM for a previous or subsequent year was also the main venue for the blank years. We also used the Financial Times to cross-check and supplement information, although its coverage of the provincial markets was fairly limited.

\footnotetext{
${ }^{5}$ Hannah (2018) has raised queries about the reliability of the IMM data. However, as discussed by Campbell et al. (2019) there are two versions of the IMM provided by Yale. There is one version, available as a single file, which has attempted to standardize the database, but is missing the original notes which has led to problems when conducting analysis. The data used in this paper is from the web interface which is highly consistent with the original IMM formatting, including any additional notes which were reported at the time.
} 
We use the information on which markets a company was chiefly traded on to assess the characteristics of the major provincial markets. We also categorize companies according to their listing strategy as reported in the IMM. 'London Only' represents those companies which were chiefly traded only on the London Stock Exchange. 'London and Provincial' are those companies which were chiefly traded on both the London Stock Exchange and one or more provincial markets. 'Provincial Only' are those companies traded solely on the regional markets. They could have been traded on multiple provincial markets or just one, but we just combine these possibilities into a single group.

The IMM generally reported what sector a company operated in, and we use their classification where possible. However, there was a large group of 'Commercial and Industrial' firms in the IMM, which were essentially miscellaneous companies. We have grouped them based on their name, and by cross-referencing with an additional industry classification scheme put together by the Yale International Center for Finance for IMM companies. As the headquarters of each company was not coded by the Yale International Center for Finance project, we have manually input this data from the IMM for companies listed at the end of each decade.

\section{The Evolution of the Provincial Stock Exchanges}

The London Stock Exchange was established in the 1690s, and for the next 150 years of its existence, trading was primarily in government securities. The main equities traded on the market over this period were those of quasi-government entities, e.g., the Bank of England, East India Company, and South Sea Company (Morgan and Thomas, 1962, p. 79; Michie, 1985, p. 62).

A stock exchange was first set up in Dublin in 1799 (Thomas, 1987, p. 536). In 1836, stock exchanges were then established in Liverpool and Manchester during the first railway 
promotion boom (Thomas, 1973). ${ }^{6}$ The second railway promotion boom of 1844-45 was accompanied by the establishment of stock exchanges in Glasgow, Aberdeen, Edinburgh, and in 12 English towns and cities (Killick and Thomas, 1970, p. 103; Thomas, 1973, p. 28-69; Michie, 2001, p. 117). ${ }^{7}$ Seven of these new English provincial stock exchanges did not survive the collapse of the railway mania, but four of them reappeared later in the century (Thomas, 1973, p. 50; Killick and Thomas, 1970, p. 104).

In the 1840s, public telegraph lines were laid which linked London and other major British cities. Over the second half of the nineteenth century, special wires were constructed which connected the various stock markets and telegraph offices were set up close to, and even in, the exchanges (Michie, 1985, p. 66). The development of telephones in the 1870s opened up two-way instantaneous communication between exchanges and with outside brokers (Michie, 1985, p. 70). By the 1890s, a system was in place that connected the London Stock Exchanges to the provincial stock exchanges through direct cables. Around 1900 the development of private telephone wires further increased the links between the offices of provincial stock-brokers and members of the London Stock Exchange (Michie, 1985, pp. 70$1)$.

There were 76 companies listed on the Liverpool Stock Exchange in 1838, but this had more than doubled to 175 in 1845 at the height of the Railway Mania. ${ }^{8}$ In the aftermath of the bursting of the railway bubble, the listings declined somewhat, with about 140 companies listed in both 1858 and 1869. During the subsequent period, which is the main focus of our analysis, the provincial markets initially expanded. Liverpool had 236 companies

\footnotetext{
${ }^{6}$ The first detailed share list for a provincial market appeared in the Liverpool Mercury on March 12, 1830, with 11 stocks listed (Thomas, 1973, p.11).

7 Stock exchanges were established in Birmingham, Bradford, Bristol, Halifax, Huddersfield, Hull, Leeds, Leicester, Newcastle, Nottingham, Sheffield, and York. There is some debate as to whether a stock exchange was formally established in Halifax (Thomas, 1973, p.64).

${ }^{8}$ The data on the Liverpool and Manchester stock exchanges in this paragraph are from their Official Price lists.
} 
listed in 1880, and Manchester had 275 companies listed in 1887. Further rapid growth can be seen thereafter, with Manchester having 506 companies listed in 1900. The expansion of the provincial official lists then slows, with a modest increase to 563 companies in 1929. There is then a decline to 467 companies in 1960.

However, these official lists do not necessarily show whether much trading was actually being conducted in these securities. To examine this further, in Table 1 we compare the Manchester Official Lists against the London Stock Exchange Daily Official List (SEDOL), which began publication in 1900. We find that 324 companies were listed on both Manchester and London in 1900, representing 64 per cent of all of Manchester's listings. By 1929, cross-listings with London made up 74 per cent of Manchester's listings, and by 1960 this had risen to 79 per cent. This indicates that the uniqueness of the Manchester list was declining, and many of the securities may only have been nominally listed there.

\section{$<<$ INSERT TABLE 1 >}

A similar conclusion can be drawn when we consider the IMM data. In 1900, of the 506 companies which were included on the Manchester Official List, the IMM included 69 per cent of them in its lists. However, only 28 per cent of this subset of companies were actually chiefly traded in Manchester, according to the IMM. By 1929, the IMM had coverage of about 70 per cent of the companies on the Manchester Official List, but indicated that only 17 per cent of this subset of firms were chiefly traded there. For companies on the London Official List, the IMM had roughly similar coverage overall, but reported much higher levels of trading actually being located there. About 85 per cent of the companies which the IMM included from the London Official List were chiefly traded in London.

For the rest of our analysis, we will focus on the IMM data. A summary of its coverage can be seen from Table 2, which reports the number of companies which were 'chiefly traded' on each market. There were 722 companies in the IMM which were reported as being chiefly 
traded on at least one market in the UK in 1869. Of these, London had 440, which was somewhat higher than the 353 chiefly traded on at least one provincial market. From 1869 to 1899, both London and the provincial markets grew in size, but London expanded much faster, with the number of companies more than doubling to 1,153 , while the number on at least one provincial market rose to 512. Thereafter, the number of companies on London continued to rise, albeit more slowly, while the number chiefly traded on provincial markets began to decline, falling to 279 by the end of 1929 , below where they had been in 1869 .

\section{$<<$ INSERT TABLE $2>>$}

The importance of the provincial markets to the trading of securities in domestic enterprises at the start of the sample period can be seen when foreign companies are excluded. In 1869 , the provincial stock exchanges had 332 domestic companies, which was considerably more than the London Stock Exchange total of 241. However, domestic listings on London grew more quickly, and by 1899 surpassed those on the provincial exchanges. By 1929, the number of domestic companies chiefly traded on London was more than double that of the provincial exchanges.

In terms of the major provincial markets, Manchester was one of the largest throughout the period, rising from 58 companies in 1869 , to 115 in 1899 , before falling back to 66 by 1929. Liverpool had 62 companies in 1869, but it did not keep pace with Manchester and it too went into decline after 1899 . Birmingham had been one of the largest in 1869 , but fell thereafter. The Scottish markets, Glasgow and Edinburgh, were also important, with both peaking around 1899, before declining to 1929 . Although other markets had lower numbers traded on them individually, when considered collectively they were also important trading venues at the beginning of the period, peaking in numbers in the $1890 \mathrm{~s}$, before declining considerably thereafter. 
Similar patterns can be seen when grouping companies by listing strategy. From Table 2, the number of companies which were 'London Only' increased steadily from 369 in 1869 to 1,226 in 1929 . By way of contrast, a pattern of expansion and contraction was evident in the listing strategies which involved the provincial markets. The number of companies chiefly traded on both 'London and Provincial' markets remained healthy, but those chiefly traded exclusively on provincial markets experienced a substantial decline in the later decades of our sample.

After the sample period covered by the IMM, the provincial stock exchanges survived for several decades. However, in the 1960s they formally merged into larger regional entities 9 . The trends in terms of the composition of the markets continued. In 1970, securities traded solely on provincial markets made up just 23 per cent of the Western Stock Exchange, and 13 per cent of securities on the Northern Stock Exchange (Thomas, 1973, p. 263). By this time, it was thought that "turnover in local shares was totally inadequate to support an efficient dealing and broking mechanism" (Thomas, 1973, p.279). With London and the provincial markets often dealing in the same stocks, a full merger was proposed in the early 1970s. London jobbers wanted to reduce the competition from country jobbing, London brokers wanted to expand nationwide, and provincial brokers/jobbers wanted direct access to London (Michie, 2001, p.457-463). In 1973 the regional exchanges amalgamated with the London Stock Exchange, so that the UK had a single national exchange (Michie, 2001, p. 501).

To analyze why companies listed on particular markets, and how this changed over time, we begin by considering the characteristics of firms which listed on them (particularly

\footnotetext{
${ }^{9}$ This was driven by the exchanges themselves (Thomas, 1973), but they were also encouraged to do so by the Jenkins Committee (Report of the Company Law Committee 1962, p.94) who thought that larger exchanges would be more capable of disciplining members, scrutinising applications for quotation, and compensating investors if a member defaulted.
} 
their geography, sector and size) before considering the characteristics of the exchanges themselves (namely their listing requirements and liquidity).

\section{Firm Characteristics}

\subsection{Firm Location}

The provincial markets were spread across the UK, so it might be expected that geography could have played a role in terms of what companies they listed. In Table 3 we cross-tabulate the location of a firm's head office with its listing type, when they first appeared in the IMM. Those firms headquartered in London, and overseas, were overwhelmingly chiefly traded on the London Stock Exchange. By way of contrast, about 81 per cent of companies with regional headquarters were chiefly traded on the provincial markets, and 66 per cent exclusively so.

\section{$<<$ INSERT TABLE $3>>$}

For many companies, it seems likely that the choice of where to base the headquarters was made first, focused on operating considerations, with the listing decision being made afterwards. At the start of our sample period many companies were based in the provinces for practical reasons. For example, railways, canals, docks, and shipping firms were geographically bound and they served customers in a fixed geographic area. Banks tended to focus on small areas so that they could monitor customers closely. Coal, iron and steel companies were also often based in the rest of the UK, with agglomeration economies in the form of transport cost savings helping to explain why these industries were based where they were.

Firms in the traditional sector of spinning and weaving were much more likely to be based in the provinces, particularly Lancashire. Natural and acquired advantages such as the availability of water power and access to coal explains why the cotton industry was originally located in this region, but the cotton textile agglomeration explains its locational persistence 
(Crafts and Wolf, 2014). Lancashire's agglomeration advantages included tacit knowledge, dense labor markets, a network of suppliers, marketing expertise and the scale of the Liverpool cotton exchange (Broadberry and Marrison, 2002; Balderston, 2010; Crafts and Wolf, 2014).

Once a company was established in a certain area there may have been a local bias which made it attractive to investors in the surrounding area. Lowenfeld $(1909, \mathrm{p} .121)$ noted that "if the question of what people think of stocks and what they consider safe is analyzed, we come again to a point of geography pure and simple". Even in modern capital markets, investors prefer to hold shares in local firms because they have easier access to information about those companies headquartered near to them (Coval and Moskowitz, 1999; Gaspar and Massa, 2007), and this was likely also the case historically (Broadbridge, 1968; Campbell and Turner, 2012; Reed, 1968; 1975; Turner, 2009; Acheson and Turner, 2011; Newton, 2010).

However, as time progressed the foundations given to the provincial markets by regional companies were undermined, partly by merger waves and partly by the emergence of new industries. Of those railways which operated within the British Isles, companies with their head office outside of London represented 49 per cent of market capitalization in 1869 , but this had fallen to just 2 per cent by 1929 . Why this dramatic shift? The government's rationalization of the UK railway sector in the Railways Act of 1921 created four railway groups or companies. This rationalization meant the disappearance of nearly 120 railway separate companies, 74 of which, according to the 1920 Stock Exchange Yearbook, had been based outside of London. The four new companies were all headquartered in London, which may have reflected a desire by the government to be able to monitor and control them closely. The railways had been increasingly regulated during the late nineteenth and early twentieth century. They had entered into direct government control during World War I, and this had 
continued until the Railways Act of 1921 created the new groupings ${ }^{10}$. The state would still be influential in the running of the new companies, and having them managed from London may have made this easier.

In 1869 , about 71 per cent of the banking sector's market capitalization was based outside London, but by 1929 this had fallen to 34 per cent. This change was largely due to amalgamations, with 116 bank mergers occurring between 1872 and 1920 (Sykes, 1926). Using various issues of the Stock Exchange Yearbook, we found that 48 of these mergers resulted in the disappearance of headquarters that had previously been outside London. One major reason for the movement of the newly merged bank headquarters to London was the concentration of expertise and human capital in the City (Michie, 1997). In addition, lower communication costs, thanks to the development and widespread use of the telephone and telegraph, made it easier for managers based in London to monitor what was happening in remote branches.

The mergers in the railway and banking sectors are plausibly exogenous events. In both industries, the shift of headquarters to London happened because of the mergers, and not because of the desire of the newly merged companies to list on the London Stock Exchange.

Campbell et al. (2019) have estimated that railways and banks were responsible for 76 per cent of market capitalization in 1869 , but this had fallen to 39 per cent by 1929 . This was mainly due to structural changes within the economy. There had been ongoing technological innovation, opening up new fields such as oil, electricity, chemicals, and consumer products such as beer and tobacco. These newer industries tended to be based in London for several reasons. Improvements in telecommunications made it much easier for companies to be controlled from a central point. Similarly, London offered transportation advantages which

${ }^{10}$ Stock Exchange Year Book, 1930, p.294 
made it possible to travel across the country quickly, with a mature railway network, shipping links, and a growing road system. There had also been the development of local railways, tramways, underground, and omnibuses, which made travel around and from London relatively easy (Michie, 1997; Scott, 1998).

London was also a global distribution and trading hub (Scott, 1998). It became a more dominant political center from 1914 onwards (Michie, 1997, p.78), and was the base of the government, the Civil Service, the military, the legal system and the British Empire. This may help to explain the strong propensity for companies which had an international focus to base themselves in London. Of the 1,651 companies in our sample which operated mainly abroad ${ }^{11}$, only 5 per cent had their offices in the provinces of the UK, about 10 per cent were based in a foreign country, with an overwhelming 85 per cent choosing to have their headquarters in London.

London also had a large and flexible workforce, which had been enlarged by the arrival of commuter trains (Crafts and Leunig, 2014). It also had a dense and unique clustering of support services for businesses (e.g., marine insurance, merchant banks, accountants, brokers etc.) which facilitated commerce (Michie, 1997, p.76; Mollan and Michie, 2012).

These changes in industry composition resulted in fewer large companies being based in the provinces. The decline in the proportion of companies in our sample which had their headquarters in the rest of the UK, outside of London, is shown in Figure 1. There is a visible connection with the proportion of companies which were chiefly traded only on provincial markets. To test empirically the relationship, we calculated the changes in each of the variables to deal with non-stationarity. We then regressed the monthly change in the

\footnotetext{
${ }^{11}$ We have based this on whether their company name suggested that they operated outside the UK, and we also referred to the Stock Exchange Yearbooks to verify if a company's operations were based overseas.
} 
proportion of companies with provincial-only listings against the change in the proportion of companies with headquarters in the rest of the UK, and find a highly significant relationship, with a $t$-statistic of 15.2 , and an R-squared of 63.4 per cent.

\section{$<$ INSERT FIGURE 1 >}

It is possible that there was also some reverse causality involved in this. It could be argued that companies increasingly chose to base themselves in London to make it more likely that they could get listed there. However, this does not seem plausible as it was still very much possible for companies based elsewhere to list on the London Stock Exchange (LSE). Only a minority of the provincial companies in our sample chose to do so, but they are clear evidence that basing themselves in the regions did not prevent a listing in London. The preferred listing venue should not therefore have been the main determinant of where the headquarters was based.

\subsection{Industry Sector and Firm Size}

The industry sector which a company was involved in may also have played a role in terms of whether a company was solely traded on London or the provincial exchanges, or whether they were cross-listed on both. Patterns in terms of this for each industry are shown in Table 4.

\section{$<<$ INSERT TABLE 4 >>}

By their nature some industries operated over several regions, and companies with their headquarters in London could still be regarded as local in other areas. For example, the network of the London and North-Western Railway spread over hundreds of miles, and included stations in major cities such as London, Liverpool and Manchester. As well as operating in multiple regions, the major railways also tended to be traded on multiple exchanges in these areas. In contrast, there were some industries whose firms tended to work 
in very small areas for monitoring purposes, such as banks, and would have been more likely to list on just a single exchange.

Those firms which were listed jointly on London and the provincial markets tended to be much larger on average, as shown in Figure 2. This may have been a spillover from some of the railways having a dual listing, but large blue-chip firms would also have been naturally more capable of attracting investors across multiple venues. Other large firms may then also have wanted to cross list across several exchanges, to achieve a certification effect which would boost their status. This may help to explain the rising proportion of firms on provincial markets which also had a listing on London.

\section{$<$ INSERT FIGURE 2 >}

Size may therefore have played a role in the listing decisions of large firms. However, it may also have been a factor at the other end of the distribution, as some exchanges imposed listing requirements which mandated that only companies of a certain size could be traded. The provincial markets tended to be quite liberal, with the minimum for Liverpool set at $£ 50,000$, and the guideline for Manchester being only that they would not quote small companies "insufficiently in the public hands" (Thomas, 1973).

For an official quotation on London there was a general policy that companies should be of "sufficient magnitude and importance" (Burhop et al., 2014, p.63). In 1902, it was suggested that firms should have a subscribed capital of at least $£ 100,000$ (Gore-Brown, 1902, p.454) $)^{12}$. However, it was possible that if a company could not meet the conditions for an official quotation they could still be traded if they applied for a Special Settlement, which required only very basic conditions to be met. These companies became more visible in 1916 when a Supplementary List was introduced by the London Stock Exchange which showed the

\footnotetext{
12 The minimum listing size for London was not particularly high by international standards. For example, Michie (1985, p.185) has calculated that in 1914 'to obtain a quotation on the New York Exchange a company had to be at least five times bigger than its London counterpart.'
} 
prices of these securities (Burhop et al., 2014, p.64; Michie, 2001, p.272). This may have attracted smaller firms to also trade there.

\subsection{Firm Characteristics and Listing Strategy}

To analyze the importance of firm characteristics as a determinant of listing strategy, we use a multinomial logit regression. In this specification, the dependent variable can take on three values depending on where a company was chiefly traded, namely a) Only London, b) Jointly London and Provincial Markets, and c) Only Provincial Markets. We choose Only London as the base group, to analyze what factors were associated with making it more or less likely that a company had some form of provincial listing rather than being traded only on London.

To analyze these factors within our multivariate analysis, we test whether a company having its headquarters in the regions (HQRest $U K)$ affected listing strategy. We also control for differences between the two principal industry sectors (IndTransport and IndFinancial), and for differences in size (MarketCap).We repeat the regressions for the last month of each decade, with the results shown in Table $5 .^{13}$

\section{$<<$ INSERT TABLE $5>>$}

The first variable to focus on is HQRest $U K$, which equals 1 if a company had its headquarters anywhere in the UK, outside of London. As was suggested from the crosstabulation in Table 3, this was a very important predictor of having a provincial listing, and was significant for both joint London and Provincial listings, and for Only Provincial listings. This finding is maintained in every decade of our sample. This implies that companies which were based in the regions were significantly more likely to have some form of provincial listing, rather than an only London listing.

\footnotetext{
${ }^{13}$ We do not use panel data techniques because some of the variables are persistent and have very little variation over time. Using a panel regression would tend to bias results in terms of significance.
} 
Companies in the transport sector were also significantly more likely to list jointly or solely on provincial markets than to be listed only on London. However, as can be seen from Table 5, this relationship broke down in the 1920s, after the grouping of the railways into a small number of very large firms. Financial companies were significantly more likely to be traded solely on provincial markets.

The size of companies had an effect at both extremes, as was suggested from the patterns observed in Figure 2. There was a positive relationship, generally significant, with having a joint London and Provincial listing. This suggests that larger companies were more likely to be cross-listed on multiple exchanges, rather than just be listed on London alone. In contrast, there was a negative relationship with an Only Provincial listing. This implies that smaller companies tended to be more often quoted on the provincial markets than on London. However, this significance breaks down towards the end of our sample period, possibly reflecting growth in the London Supplementary List, which may have allowed smaller companies to trade on London.

These results suggest that firm characteristics, namely location, industry and size, affected listing strategy. We now go on to analyze exchange characteristics, by considering how listing strategy was connected with governance requirements and liquidity.

\section{Characteristics of the Exchanges}

\subsection{Liquidity of the Exchanges}

The liquidity of stock exchanges matters to investors who want to convert their shares into cash. The rise and attractiveness of the provincial markets may, therefore, have been because they offered superior liquidity to London. Concomitantly, their demise may have been partially attributable to the cessation of this liquidity advantage. 
In order to test this conjecture, we need to measure the liquidity of the various stock markets. The generally preferred approach to looking at liquidity is to use bid-ask spreads. Unfortunately, the Investor's Monthly Manual did not report separate bid and ask prices. To overcome this we use a proxy, based on the approach of Bekaert et al. (2007) who analyze liquidity in modern emerging markets. This measure implicitly assumes that a security traded if its price changed during a particular month, and that it did not trade if its price remained constant. This may understate liquidity, as some trades may have taken place and prices just remained the same, but this should not lead to bias between markets or over time. Goyenko et al. (2009) find that this measure performs well against other liquidity measures in modern markets. Campbell et al. (2018) also find that it is a good measure historically, and is significantly related to bid-ask spreads when they look at the London Stock Exchange between 1825 and 1870 . We begin by evaluating whether a security traded in a particular month, and then aggregate this for each market by calculating the proportion of stocks which traded.

Liquidity on each market may have been affected by several factors. Firstly, there were some regulations imposed by the exchanges which were aimed at promoting trading. London did not allow firms to purchase their own shares, and required companies to allot two-thirds of their capital to the public (Melsheimer and Laurence, 1879, 1884). In 1887 a court decision made it illegal for any company to purchase their own shares, meaning this rule also applied to the provincial markets. The two-thirds requirement was also put forward by the Council of Associated Stock Exchanges for the provincial markets, but this was objected to by the Manchester exchange (Thomas, 1973, p.198) ${ }^{14}$

\footnotetext{
14 There has been a recent debate about how strictly the two-thirds requirement was enforced by London (Hannah, 2007 and Cheffins et al., 2013).
} 
Another difference between the exchanges, also related to liquidity, could be to do with the market microstructure. In London a dual system was used which separated brokers from jobbers, whereas the division was not explicit on the provincial exchanges (Lavington, 1921, p.221). If this affected the ability to execute trades quickly this may have led on to differences in liquidity, which could have been influential.

Our results, reported in Table 6 , show that liquidity was as high, if not higher, on provincial markets than London. For the overall period, an average of 50 per cent of securities traded on London each month, and for provincial markets it was 53 per cent. While these averages may seem quite low, it is consistent with the qualitative evidence. Lavington (1921) cites the investment writer Lowenfeld as saying that about 5,000 securities were officially quoted in British stock exchanges, but less than 400 had a free market.

\section{$<<$ INSERT TABLE $6>>$}

Our measure of liquidity for each market relies on estimating the proportion of securities traded on a market compared to all of the securities on that market. Our estimates of average liquidity for each exchange could therefore have been affected if our data source was more likely to include only the most liquid assets for some exchanges. However, our findings are consistent with some qualitative contemporary observations on bid-ask spreads. The Economist noted that, compared to London, if a broker "went to a provincial stock exchange he would probably be able to buy or sell on rather better terms as regards perhaps a couple of hundred shares". ${ }^{15}$ In other words, liquidity for small trades was generally as good, if not better, on the provincial markets than London.

To test this empirically we regress binary variables for listing strategies (London\&Provincial and ProvincialOnly) on liquidity to test if they are correlated. We also

\footnotetext{
${ }^{15}$ The Economist, September 7, 1907, p.1499.
} 
control for other variables used in our previous regressions. The results in Table 7 suggest that, for most of the period, firms which were listed jointly on London and the provincial markets, or only on provincial markets, were more liquid than those listed only on London.

\section{$<<$ INSERT TABLE 7>>}

The problem that the Economist saw with the provincial markets was not the size of the bid-ask spread, it was the depth of the market: "it is excellent to be able to deal a threepenny margin between buying and selling, but if the price extends only to 500 shares, it is obviously better to have another market where the broker can deal at a shilling margin in 2,000 shares, if he wants to". ${ }^{16}$ London was likely to offer more depth of trading in large companies, but it did not necessarily ensure that small companies would be very actively traded.

The results in Table 7 suggest that any liquidity advantage to having a provincial listing had disappeared by the 1920s. One factor that may have affected liquidity over time was the trading links between the provinces and London. For many years provincial brokers were able to deal directly with London jobbers. This helped to facilitate 'shunting', which meant that any arbitrage opportunities involving the prices of companies cross-listed on multiple exchanges were quickly exploited, and prices were consistent in each market. Some London 'shunters' may also have effectively acted as jobbers in provincial stocks (Michie, 1985, p.74). However, in 1909 the LSE passed a rule which meant that brokers could not quote prices for non-members and no jobber could deal for non-members, and another rule was passed in 1912 which established minimum commissions (Michie, 1985, p. 77; 2001, p. 120-2).

\footnotetext{
${ }^{16}$ The Economist, September 7, 1907, p.1499.
} 
This made it more difficult for provincial brokers to access the London market. If investors who lived in the provinces still wanted to trade in LSE securities, they would have to find a London broker, which would have been possible given improvements in communication technology. Alternatively, they could use a provincial broker and trade on the provincial markets. If they chose the former this would increase business for the London brokers, if they chose the latter it would reduce liquidity on London but increase it in the provinces. The results in Table 6 suggest that LSE liquidity barely changed after the rules were introduced, suggesting that the additional restrictions and minimum commissions did not reduce trading there. ${ }^{17}$ Interestingly, provincial liquidity declined during the 1920 s. There may have been other factors involved in this, but it could have been indirectly connected to the rule changes if the reduced links between London and provincial brokers also made it more difficult for London based investors to trade in provincial stocks.

Overall, the results on liquidity suggest that the provincial markets offered superior liquidity than the London market until the 1920s. Therefore, the decline in the provincial markets which had started around 1900 cannot be attributed to the loss of this liquidity advantage. Nevertheless, the relative decline of the provincial markets accelerated during the 1920s, possibly due to the loss of this liquidity advantage.

\subsection{Stock Exchange Governance Requirements}

The initial popularity of the provincial stock exchanges may simply have been due to them having less onerous listing requirements with regards to firm governance than the London market. When a company wanted to list on an exchange, it would typically issue a prospectus showing details of the offer and would invite applications for shares. They usually included a

\footnotetext{
${ }^{17}$ This was despite the perception reported in a survey in 1930 that provincial brokers now did more business amongst themselves rather than with London (Michie, 2001, p.218)
} 
note similar to the one by Henry Pooley and Son (The Times Book of Prospectuses, 1900, p.47) which said "it is intended to apply in due course for an official quotation for the Debenture Stock and Shares on the London, Glasgow, Liverpool, Manchester and Birmingham Stock Exchanges". ${ }^{18}$ A consideration for companies that wanted to get listed was whether it would imply any changes to their governance structure. From 1862 to 1899 , there were few legal restrictions imposed on companies in terms of shareholder protections, but the exchanges could impose their own requirements. To examine this further, we have obtained data from Acheson et al. (2019), who record in detail which shareholder protection provisions were included by companies in their articles of association during the period before $1900 .{ }^{19}$ They include 18 provisions which could potentially have protected shareholders, such as whether the company committed to having its accounts audited, proxy voting, and preemptive rights on new share issues.

From the sample provided by Acheson et al. (2019), we have data on 189 companies listed only on London, 131 companies only on the provincial markets, and 26 listed on both. In Table 8, we show the average number of provisions included in their articles of associations (SPITotal) by each of these types of companies. We find that firms only on the provincial markets actually had slightly higher shareholder protections overall. When looking at the 11 provisions recommended by the government in Table A of the 1862 Companies Act (Default1862), the firms only on provincial markets also had more than the London listings.

\footnotetext{
${ }^{18}$ There is little evidence to suggest that the process of underwriting had a major influence on where the company would be traded. The initial issue of shares by very large companies in London may have been underwritten by specialist banks, but in most cases, it was by a diverse group of promoters, both in London and the provinces (Lavington, 1921, p.183). See also Burhop (2014) and Chambers and Dimson (2009)

${ }^{19}$ Acheson et al. (2019) report that their sample was broadly similar to the wider capital market across a range of measures, but there were some differences. It did not include railways, and included slightly more finance and industrial/commercial firms. The average number of markets that firms were traded on was similar to the broader population, but slightly fewer with a London listing. The sample companies are slightly smaller than average, but this is mainly driven by the absence of very large firms.
} 
Six of the provisions would go on to be required by the London Stock Exchange in 1902 (LSE1902) according to Gore-Brown (1902). Of these, the provincial companies had slightly fewer, although notably the LSE firms also had less than the maximum, confirming that these requirements were not imposed until later.

\section{$<<$ INSERT TABLE 8>>}

This univariate analysis suggests that by some measures companies only on London had higher shareholder protections, but by other measures companies listed only on the provincial markets were higher. These conflicting results make it difficult to conclude that governance requirements imposed by the exchanges had a major impact during this period. In Table 9 we go on to regress dummy variables for listing strategy against our measures of shareholder protections, controlling for other variables. However, none of the governance measures had a significant relationship with the listing decision.

\section{$<<$ INSERT TABLE $9>>$}

It therefore seems unlikely that burdensome regulations on governance would have been the reason for companies avoiding London before 1900, when the provincial markets were at their height. In the twentieth century, the provincial markets followed London in terms of listing requirements (Thomas, 1973, p.198). It was agreed that there should be general uniformity with London in most matters, but local committees could waive certain rules (Thomas, 1973, p.178). If the provincial markets did exercise discretion in waiving some provisions, they do not seem to have benefitted much, as London became ever more dominant.

\section{Conclusions}

In the late nineteenth century, the provincial markets were an important venue for regional companies to list. By facilitating trade in their securities, they made it easier for these firms to raise capital from local investors. In this sense, they should generally be seen as being 
complementary to the London market which provided a venue for the trading of shares of companies based in the capital, but which may have operated nationally or internationally.

Our findings suggest that the uniqueness of the provincial markets was gradually eroded over time due to merger waves and the emergence of new industries. The merger waves resulted in firms that were once tied to a regional area being merged into national firms which were headquartered in London rather than provincial cities. Also, as different technologies emerged, and consumer products became more prominent, new companies became increasingly based in London. They benefited from agglomeration economies arising from advanced transport and communication networks, closeness to the government and civil service, a concentration of professional services, and a large and flexible workforce. With their headquarters in London they also tended to list on the London Stock Exchange.

As time progressed, more regional companies also wanted to be cross-listed in London in search of a certification effect. A further blow to the uniqueness of the provincial markets came with the expansion of the Supplementary List of the LSE, making it easier for small regional companies to get traded on London. By the last decade of our analysis, the uniqueness of the provincial markets had virtually disappeared, and they were increasingly in direct competition with London. Subsequently, the individual exchanges eventually merged with each other into larger regional exchanges, and then merged with London soon afterwards.

The history of the provincial exchanges may have implications for modern markets, particularly those which are relatively small. Our analysis suggests that having a base of unique companies could be a valuable way for them to differentiate themselves. National exchanges can survive, and there may even be a potential for some new regional exchanges, 
but they need to be located in areas where there are a number of large enterprises which are not listed elsewhere. ${ }^{20}$ This was the foundation on which the provincial exchanges were built.

\footnotetext{
${ }^{20}$ Despite improvements in communication technologies, there still seems to be a strong influence from location. For example, the World Federation of Exchanges (2019) indicates that for the 77 stock markets that they cover, an average of 92 per cent of their listings are domestic. Even within countries, there is still a strong regional influence with UK listed firms clustered in London and the South-East.
} 


\section{References}

Acheson, Graeme G. and John D. Turner. "Investor Behavior in a Nascent Capital Market: Scottish Bank Shareholders in the Nineteenth Century." Economic History Review 64, no. 1 (2011): 188-213.

Acheson, Graeme G., Gareth Campbell and John D. Turner. "Private Contracting, Law and Finance." Review of Financial Studies, forthcoming (2019).

Amihud, Yakov, Beni Lauterbach, and Haim Mendelson. "The Value of Trading Consolidation: Evidence from the Exercise of Warrants." Journal of Financial and Quantitative Analysis 38, no. 4 (2003): 829-46.

Arnold, Tom, Philip Hersch, J. Harold Mulherin, and Jeffry Netter. "Merging Markets." The Journal of Finance 54, no. 3 (1999): 1083-1107.

Balderston, Theo. "The Economics of Abundance: Coal and Cotton in Lancashire and the World." Economic History Review 63, no.3 (2010): 569-80.

Bekaert, Geert, Campbell R. Harvey, and Christian Lundblad. "Liquidity and Expected Returns: Lessons from Emerging Markets." Review of Financial Studies 20, no. 6 (2007): 1783-1831.

Bennett, Paul, and Li Wei. "Market Structure, Fragmentation, and Market Quality." Journal of Financial Markets 9, no. 1 (2006): 49-78.

Broadberry, Stephen and Andrew Marrison. "External Economies of Scale in the Lancashire Cotton Industry." Economic History Review 55, no. 1 (2002): 51-77.

Broadbridge, S. A. "The Sources of Railway Share Capital." In Railways in the Victorian Economy: Studies in Finance and Economic Growth, edited by M. C. Reed, 184-211. New York: Augustus M. Kelley, 1968.

Brown, William, J. Harold Mulherin, and Marc D. Weidenmier. "Competing with the New York Stock Exchange.” The Quarterly Journal of Economics 123, no. 4 (2008): 1679-1719.

Burhop, Carsten and Sybille Lehmann-Hasemeyer, S. "The Berlin Stock Exchange and the Geography of German Stock Markets in 1913." European Review of Economic History 20, no.4 (2016): 429-451.

Burhop, Carsten, David Chambers, and Brian Cheffins. "Regulating IPOs: Evidence from Going Public in London, 1900-1913.” Explorations in Economic History 51 (2014), no.1: 6076.

Campbell, Gareth, John D. Turner, and Qing Ye. "The Liquidity of the London Capital Markets, 1825-1870.” Economic History Review 71, no.3 (2018): 823-852.

Campbell, Gareth and John D. Turner. "Dispelling the Myth of the Naive Investor during the Railway "Mania" Boom in Britain, 1845-46." Business History Review 86, no. 1 (2012): 3-41. 
Campbell, Gareth, Richard S. Grossman, and John D. Turner. "Before the Cult of Equity: New Monthly Indices of the British Share Market, 1829-1929." CEPR Discussion Paper Series, DP13717 (2019).

Capie, Forrest, and Alan Webber. A Monetary History of the United Kingdom: 1870-1982. Routledge, 1985.

Chabot, Benjamin R. and Christopher J. Kurz. "That's Where the Money Was: Foreign Bias and English Investment Abroad, 1866-1907." Economic Journal 120, no. 1 (2010): 1056-79.

Chambers, David and Elroy Dimson. "IPO Underpricing Over the Very Long Run." Journal of Finance 64, no. 3 (2009): 1407-43.

Cheffins, Brian, Dimitri Koustas, and David Chambers, "Ownership Dispersion and the London Stock Exchange's 'Two-Thirds Rule': An Empirical Test.” Business History 55, no. 4 (2013): 670-693.

Coval, Joshua D. and Tobias J. Moskowitz. "Home Bias at Home: Local Equity in Domestic Portfolios.” The Journal of Finance 54, no. 6 (1999): 2045-2073.

Crafts, Nicholas and Nikolaus Wolf. "The Location of the UK Cotton Textiles Industry in 1838: A Quantitative Analysis.” Journal of Economic History 74, no.4 (2014): 1103-39.

Crafts, Nicholas and Leunig, Timothy. "Transport Improvements, Agglomeration Economies and City Productivity: At What Point Did Nineteenth Century Transport Raise British Wages." LSE mimeo, 2014.

Edelstein, Michael. Overseas Investment in the Age of High Imperialism: The United Kingdom, 1850-1914. New York: Columbia University Press, 1982.

Fama, Eugene F., and Kenneth R. French. "Common Risk Factors in the Returns on Stocks and Bonds.” Journal of Financial Economics 33, no. 1 (1993): 3-56.

Fama, Eugene F., and Kenneth R. French. "Disappearing Dividends: Changing Firm Characteristics or Lower Propensity to Pay?" Journal of Financial Economics 60, no. 1, (2001): 3-43.

Fink, Jason, Kristin E. Fink and James P. Weston. "Competition on the Nasdaq and the Growth of Electronic Communication Networks." Journal of Banking \& Finance 30, no.9 (2006): 2537-2559.

Gaspar, Jose-Miguel and Massimo Massa. "Local Ownership as Private Information: Evidence on the Monitoring-liquidity Trade-off." Journal of Financial Economics 83, no.3 (2007): 751792.

Goetzmann, William N. and Andrey D. Ukhov. "British Investment Overseas 1870-1913: A Modern Portfolio Theory Approach.” Review of Finance 10, no. 2 (2006): 261-300.

Gore-Browne, Francis and William Jordan. A Handy Book on the Formation, Management and Winding Up of Joint Stock Companies. 19th ed. London: Jordan \& Sons, Limited, 1896. 
Gore-Browne, Francis. A Handy Book on the Formation, Management and Winding Up of Joint Stock Companies. 24th ed. London: Jordan \& Sons, Limited, 1902.

Goyenko, Ruslan Y., and Andrey D. Ukhov. "Stock and Bond Market Liquidity: A Long-Run Empirical Analysis", Journal of Financial and Quantitative Analysis 44, no. 1 (2009): 189212.

Grossman, Richard S. "Bloody Foreigners! Overseas Equity on the London Stock Exchange, 1869-1928”, Economic History Review 68, no. 2 (2015): 471-521.

Hamilton, James L. "Marketplace Fragmentation, Competition, and the Efficiency of the Stock Exchange." The Journal of Finance 34, no. 1 (1979): 171-187.

Hannah, Leslie. "The 'Divorce' of Ownership from Control from 1900 Onwards: ReCalibrating Imagined Global Trends.” Business History 49, no. 4 (2007): 404-438.

Hannah, Leslie. "The London Stock Exchange, 1869-1929: New Statistics For Old?" The Economic History Review 71, no. 4 (2018): 1349-1356.

Hautcoeur, Pierre-Cyrille and Angelo Riva. "The Paris Financial Market in the Nineteenth Century: Complementarities and Competition in Microstructures." Economic History Review 65, no. 4 (2012): 1326-1353.

He, Peng W., Elvis Jarnecic and Yubo Liu. "The Determinants of Alternative Trading Venue Market Share: Global Evidence from the Introduction of Chi-X." Journal of Financial Markets, 22, no.1 (2015) 27-49.

Kennedy, William P. Industrial Structure, Capital Markets and the Origins of British Economic Decline. Cambridge: Cambridge University Press, 1987.

Killick, J. R. and W. A. Thomas. "The Provincial Stock Exchanges, 1830-1870.” The Economic History Review 23, no. 1 (1970): 96-111.

Lamoreaux, Naomi R., Margaret Levenstein, Kenneth L. Sokoloff. "Financing Invention during the Second Industrial Revolution: Cleveland, Ohio, 1870-1920." In Financing Innovation in the United States, 1870 to the Present, edited by Naomi R. Lamoreaux and Kenneth L. Sokoloff, 39-84. Cambridge, MA: The MIT Press, 2004.

Lavington, F. The English Capital Market. London: Routledge, 1921.

Lowenfeld, Henry. Investment: An Exact Science. London: The Financial Review of Reviews, 1909.

Melsheimer, Rudolph Eyre and Walter Laurence. The Law and Customs of the London Stock Exchange. London: Sweet and Maxwell, 1905.

Michie, Ranald C. "The London Stock Exchange and the British Securities Market 18501914." Economic History Review 38, no. 1 (1985): 61-82. 
Michie, Ranald C. "The London and New York Stock Exchanges, 1850-1914." Journal of Economic History 46, no. 1 (1986): 171-187.

Michie, Ranald C. "London and the Process of Economic Growth since 1750." The London Journal 22, no.1 (1997): 63-90.

Michie, Ranald C. The London Stock Exchange: A History. Oxford: Oxford University Press, 2001.

Mollan, Simon and Ranald C. Michie. "The City of London as an International Commercial and Financial Center since 1900." Enterprise and Society 13, no. 3 (2012): 538-87.

Morgan, E. Victor and W. A. Thomas. The Stock Exchange: Its History and Functions. London: Elek Books, 1962.

Newton, Lucy A. "The Birth of Joint-Stock Banking: England and New England Compared." Business History Review 84, no. 1 (2010): 27-52.

Nishimura, Shizuya. The Decline of Inland Bills of Exchange in the London Money Market, 1855-1913. Cambridge: Cambridge University Press, 1971.

O'Hara, Maureen and Mao Ye . "Is Market Fragmentation Harming Market Quality?" Journal of Financial Economics 100, no.3 (2011): 459-474.

O'Sullivan, Mary. "The Expansion of the U.S. Stock Market, 1885-1930: Historical Facts and Theoretical Fashions", Enterprise and Society 8, no. 3 (2007): 489-542.

Parliamentary Papers, Report from the Select Committee on Bank Acts, 6.1 (1857)

Pollard, Sidney. “Capital Exports, 1870-1914: Harmful or Beneficial?” Economic History Review 38, no. 4 (1985): 489-514.

Pukthuanthong, Kuntara, and Richard Roll. "Global Market Integration: An Alternative Measure and Its Application.” Journal of Financial Economics 94, no. 2 (2009): 214-232.

Reed, M. C. "Railways and the Growth of the Capital Market." In Railways in the Victorian Economy: Studies in Finance and Economic Growth, edited by M. C. Reed, 162-83. New York: Augustus M. Kelley, 1968.

Reed, M. C. Investment in Railways in Britain 1820-1844: A Study in the Development of the Capital Market. Oxford: Clarendon Press, 1975.

Report of the Company Law Committee 1962 (Jenkins Committee)

Scott, Peter. "The Location of Early Overseas Multinationals in Britain, 1900-1939: Patterns and Determinants." Regional Studies 32, no.6 (1998): 489-501.

Stock Exchange Yearbook, various issues.

Sykes, Joseph. The Amalgamation Movement in English Banking, 1825-1924. London: P.S. King \& Son, 1926. 
The Times. The Times Book of Prospectuses, London, 1900.

Thomas, W. A. The Provincial Stock Exchanges. London: Frank Cass, 1973.

Thomas, W. A. "The evolution of a capital market: the case of Ireland". Journal of European Economic History 16, no. 3 (1987): 527-60.

Turner, John D. "Wider Share Ownership?: Investors in English Bank Shares in the Nineteenth Century." Economic History Review 62, no. 1 (2009): 167-92.

White, Eugene N. "Competition Among the Exchanges before the SEC: Was the NYSE a Natural Hegemon?" Financial History Review 20, no. 1 (2013): 29-48.

World Federation of Exchanges. Annual Statistics Guide, 2019. 


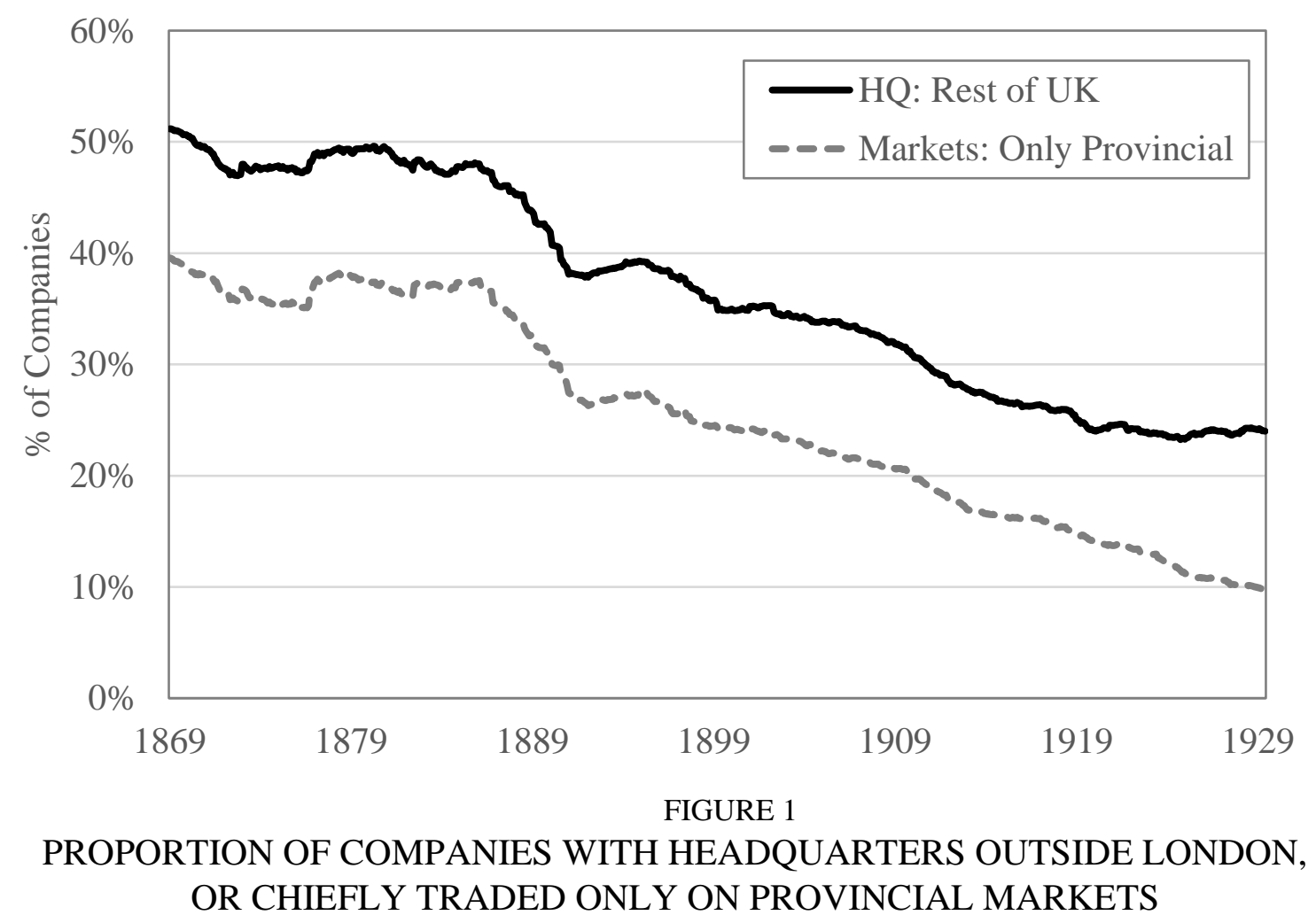

Notes: 'HQ: Rest of UK' shows the percentage of companies listed in the UK whose headquarters were based in regions outside London. 'Markets: Only Provincial' shows the percentage of companies whose securities were traded only on provincial markets. 


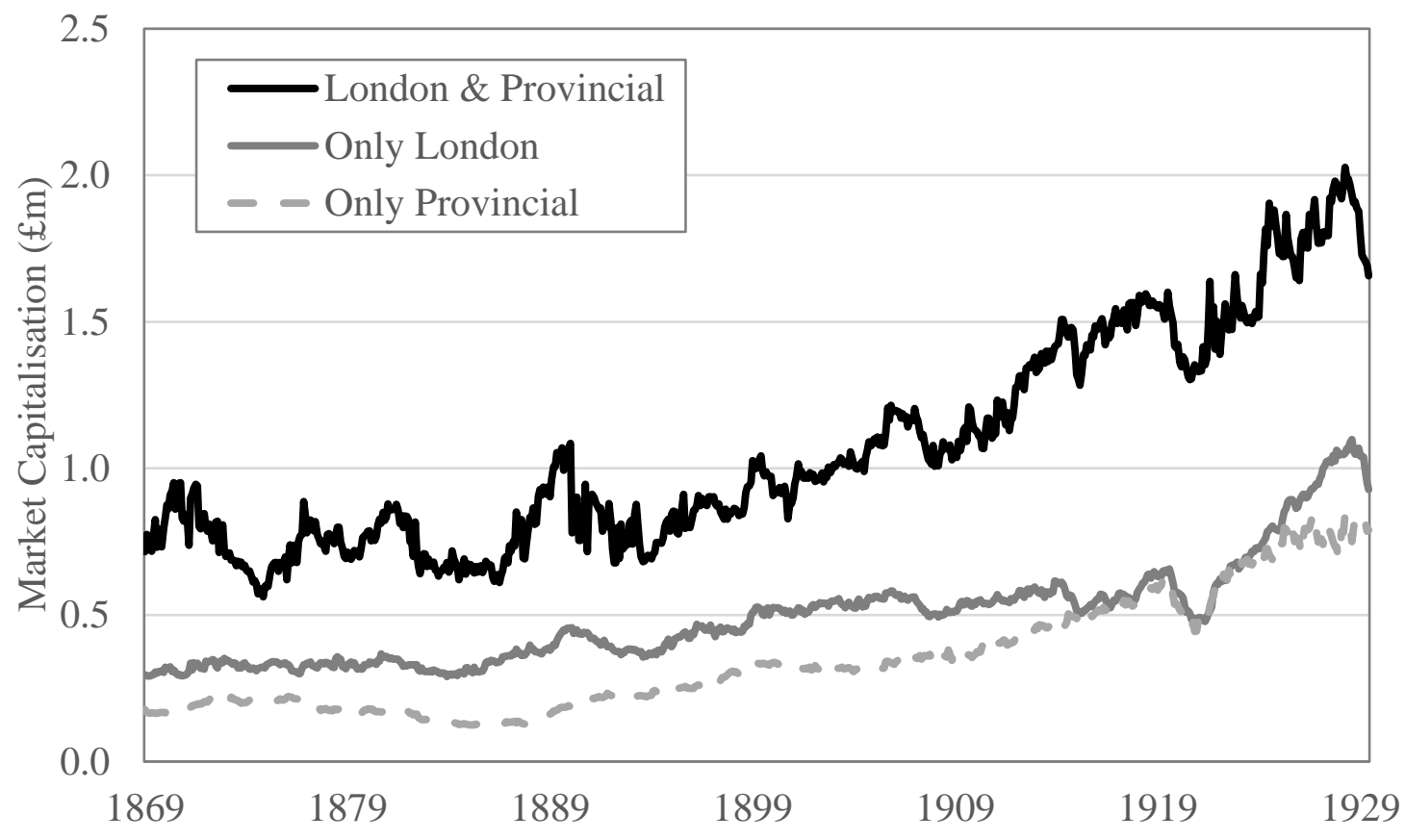

FIGURE 2

MEDIAN SIZE OF COMPANIES BY LISTING TYPE

Notes: The market capitalization of each company was calculated each month by multiplying the number of shares by the price, and then summing across all of the securities listed for that company. The median company size was then calculated each month for companies which were cross-listed on both London and the Provincial markets (London \& Provincial), or solely on London (Only London) or solely on the provincial exchanges (Only Provincial). 
TABLE 1

NUMBER OF COMPANIES ON OFFICIAL LISTS AND

INVESTOR'S MONTHLY MANUAL

\begin{tabular}{lccc}
\hline \hline & 1900 & 1929 & 1960 \\
\hline Panel A: Manchester & 506 & 563 & 467 \\
Companies in Manchester Official List & 69 & 70 & - \\
Of which, \% in IMM & 28 & 17 & - \\
Of those in IMM, \% Chiefly Traded in Manchester & & & \\
\hline Panel B: London & 1566 & 2152 & 4323 \\
Companies in London Official List & 77 & 63 & - \\
Of which, \% in IMM & 85 & 85 & - \\
Of those in IMM, \% Chiefly Traded in London & & & \\
\hline Panel C: Cross-Listed on both Manchester and London & 324 & 415 & 370 \\
Companies on both Manchester \& London Official Lists & 64 & 74 & 79 \\
\% of total Manchester listed companies & 21 & 19 & 9 \\
\% of total London listed companies & & & \\
\hline \hline
\end{tabular}

Source: Calculated from Official Price Lists of Liverpool, Manchester and London Stock Exchanges, and the Investor's Monthly Manual. 
TABLE 2

NUMBER OF COMPANIES REPORTED IN INVESTOR'S MONTHLY MANUAL AS BEING 'CHIEFLY TRADED' ON EACH STOCK EXCHANGE

\begin{tabular}{lccccccc}
\hline \hline & 1869 & 1879 & 1889 & 1899 & 1909 & 1919 & 1929 \\
\hline Domestic and international companies & & & & & & & \\
UK and Ireland (1+2+3) & 722 & 1005 & 1241 & 1518 & 1647 & 1523 & 1505 \\
London Stock Exchange (1+2) & 440 & 628 & 858 & 1153 & 1312 & 1301 & 1360 \\
Provincial stock exchanges (2+3) & 353 & 468 & 480 & 512 & 480 & 363 & 279 \\
\hline Listing strategy & & & & & & & \\
London Only (1) & 369 & 537 & 761 & 1006 & 1167 & 1160 & 1226 \\
London \& Provincial (2) & 71 & 91 & 97 & 147 & 145 & 141 & 134 \\
Provincial Only (3) & 282 & 377 & 383 & 365 & 335 & 222 & 145 \\
\hline Provincial stock exchanges & & & & & & & \\
Birmingham & 60 & 59 & 39 & 40 & 36 & 29 & 28 \\
Edinburgh & 53 & 74 & 90 & 89 & 86 & 72 & 56 \\
Glasgow & 42 & 56 & 55 & 66 & 69 & 58 & 40 \\
Liverpool & 62 & 79 & 79 & 83 & 71 & 60 & 37 \\
Manchester & 58 & 84 & 100 & 115 & 112 & 89 & 66 \\
Other Minor Markets & 153 & 214 & 227 & 223 & 199 & 126 & 95 \\
\hline Domestic companies & & & & & & & \\
UK and Ireland & 523 & 684 & 738 & 904 & 959 & 803 & 804 \\
London Stock Exchange & 241 & 316 & 388 & 569 & 659 & 605 & 674 \\
Provincial stock exchanges & 332 & 432 & 417 & 453 & 426 & 319 & 249 \\
\hline Unknown & 122 & 48 & 73 & 177 & 93 & 201 & 158 \\
\hline \hline
\end{tabular}

Notes: Includes any company with ordinary equity, preference shares and debt reported in the Investor's Monthly Manual. 'Other Minor Markets' include small markets such as Aberdeen, Bath, Belfast, Bradford, Bristol, Cardiff, Cork, Dublin, Dundee, Halifax, Huddersfield, Hull, Lancaster, Leeds, Newcastle, Newport, Norwich, Nottingham, Oldham, Rochdale, Sheffield, Swansea, Warrington and York. The listing strategies were defined as follows: 'London Only' are securities which were chiefly traded only on the London Stock Exchange; 'London \& Provincial' are securities which were chiefly traded on the London Stock Exchange and other regional stock exchanges; 'Provincial Only' are securities which were chiefly traded on just provincial markets. 'Unknown' are those securities which were in the dataset, but were not reported to be chiefly traded on any stock exchange according to the Investor's Monthly Manual.

Source: Authors' calculations based on data from Investor's Monthly Manual. 
TABLE 3

LISTING STRATEGIES OF COMPANIES BY LOCATION OF THEIR HEADQUARTERS

\begin{tabular}{lcccc}
\hline \hline & $\begin{array}{c}\text { London } \\
\text { Only } \\
(\%)\end{array}$ & $\begin{array}{c}\text { London \& } \\
\text { Provincial } \\
(\%)\end{array}$ & $\begin{array}{c}\text { Provincial } \\
\text { Only } \\
(\%)\end{array}$ & $\begin{array}{c}\text { Provincial } \\
\text { Total } \\
(\%)\end{array}$ \\
& $(1)$ & $(2)$ & $(3)$ & $(4)=(2+3)$ \\
\hline Headquarters & & & & \\
London & 94 & 4 & 2 & 6 \\
Foreign & 91 & 4 & 3 & 7 \\
Rest of UK & 18 & 16 & 66 & 81 \\
\hline Headquarters by UK region & & & & \\
Eastern & 94 & 0 & 6 & 6 \\
South East & 74 & 3 & 23 & 26 \\
East Midlands & 52 & 9 & 39 & 48 \\
South West & 42 & 15 & 40 & 55 \\
Wales & 29 & 24 & 47 & 71 \\
West Midlands & 24 & 11 & 66 & 76 \\
North East & 21 & 28 & 51 & 79 \\
North West & 10 & 22 & 66 & 88 \\
Yorkshire and the Humber & 9 & 20 & 70 & 90 \\
Scotland & 8 & 13 & 79 & 92 \\
Ireland & 6 & 6 & 88 & 94 \\
Northern Ireland & 0 & 5 & 95 & 100 \\
\hline \hline
\end{tabular}

Notes: Analysis is based on when a company was first listed. Company headquarters were reported in the Investor's Monthly Manual and were coded into regions. The listing strategies were defined as follows: 'London Only' are securities which were chiefly traded only on the London Stock Exchange; 'London \& Provincial' are securities which were chiefly traded on the London Stock Exchange and other regional stock exchanges; 'Provincial Only' are securities which were chiefly traded just on provincial markets. Northern Ireland only existed as a separate country during the last decade of our sample, but we treat it as a separate region for the entire period.

Source: Authors' calculations based on data from Investor's Monthly Manual. 
TABLE 4

INDUSTRY VERSUS WHERE CHIEFLY TRADED

\begin{tabular}{|c|c|c|c|c|}
\hline & $\begin{array}{c}\text { London } \\
\text { Only } \\
(\%) \\
(1) \\
\end{array}$ & $\begin{array}{c}\text { London \& } \\
\text { Provincial } \\
(\%) \\
(2) \\
\end{array}$ & $\begin{array}{c}\text { Provincial } \\
\text { Only } \\
(\%) \\
(3) \\
\end{array}$ & $\begin{array}{c}\text { Provincial } \\
\text { Total } \\
(\%) \\
(4)=(2+3)\end{array}$ \\
\hline Canals and Docks & 35 & 8 & 57 & 65 \\
\hline Spinning and Weaving & 35 & 9 & 56 & 65 \\
\hline Coal, Iron, Steel, Metals & 36 & 15 & 49 & 64 \\
\hline Shipping & 53 & 14 & 34 & 47 \\
\hline Insurance & 56 & 11 & 33 & 44 \\
\hline Banks & 53 & 2 & 41 & 43 \\
\hline Manufacturing & 57 & 9 & 34 & 43 \\
\hline Oil & 66 & 4 & 30 & 34 \\
\hline Breweries & 68 & 20 & 12 & 32 \\
\hline Chemicals & 69 & 9 & 21 & 31 \\
\hline Land, Mortgage, Financial & 73 & 3 & 24 & 27 \\
\hline Electricity, Gas, Light, Water & 75 & 5 & 20 & 25 \\
\hline Railways & 76 & 10 & 14 & 23 \\
\hline Building & 77 & 2 & 21 & 23 \\
\hline Services & 79 & 2 & 20 & 21 \\
\hline Paper and Publishing & 79 & 2 & 19 & 21 \\
\hline Trusts & 82 & 10 & 9 & 18 \\
\hline Retail & 84 & 3 & 14 & 16 \\
\hline Food, Drink, Tobacco & 86 & 6 & 8 & 14 \\
\hline Telegraphs & 87 & 11 & 1 & 13 \\
\hline Tea, Coffee, Rubber & 95 & 2 & 3 & 5 \\
\hline Mines & 94 & 2 & 3 & 5 \\
\hline
\end{tabular}

Notes: Industries are generally consistent with how they were originally reported in the IMM, but we have split companies which had been included in the miscellaneous 'Commercial and Industrial' into more detailed sub-categories. Includes companies which operate mainly overseas, explaining why railways are reported as being frequently listed on only London.

Source: Authors' calculations based on data from Investor's Monthly Manual. 
TABLE 5

MULTINOMINAL LOGIT REGRESSIONS EXPLAINING DETERMINANTS OF WHICH MARKETS COMPANIES WERE LISTED ON

\begin{tabular}{|c|c|c|c|c|c|c|c|}
\hline \multicolumn{8}{|c|}{ Panel A: Chiefly Traded Jointly on London and Provincial Markets } \\
\hline & 1869 & 1879 & 1889 & 1899 & 1909 & 1919 & 1929 \\
\hline HQRestUK & $\begin{array}{c}3.303 * * * \\
(0.400)\end{array}$ & $\begin{array}{c}2.837 * * * \\
(0.309)\end{array}$ & $\begin{array}{c}2.958 * * * \\
(0.284)\end{array}$ & $\begin{array}{c}3.717 * * * \\
(0.234)\end{array}$ & $\begin{array}{c}3.556 * * * \\
(0.220)\end{array}$ & $\begin{array}{c}3.743 * * * \\
(0.231)\end{array}$ & $\begin{array}{c}3.483 * * * \\
(0.240)\end{array}$ \\
\hline IndTransport & $\begin{array}{c}2.093 * * * \\
(0.581)\end{array}$ & $\begin{array}{c}1.722 * * * \\
(0.383)\end{array}$ & $\begin{array}{c}1.317 * * * \\
(0.337)\end{array}$ & $\begin{array}{c}0.949 * * * \\
(0.264)\end{array}$ & $\begin{array}{l}0.511 * \\
(0.267)\end{array}$ & $\begin{array}{c}0.726 \text { *** } \\
(0.266)\end{array}$ & $\begin{array}{c}0.150 \\
(0.329)\end{array}$ \\
\hline IndFinancial & $\begin{array}{l}1.118^{* *} \\
(0.565)\end{array}$ & $\begin{array}{c}0.590 \\
(0.394)\end{array}$ & $\begin{array}{c}0.903^{* *} \\
(0.358)\end{array}$ & $\begin{array}{c}0.500 \\
(0.308)\end{array}$ & $\begin{array}{c}0.288 \\
(0.297)\end{array}$ & $\begin{array}{c}0.422 \\
(0.307)\end{array}$ & $\begin{array}{c}0.168 \\
(0.299)\end{array}$ \\
\hline MarketCap & $\begin{array}{c}0.031 \\
(0.019)\end{array}$ & $\begin{array}{c}0.015 \\
(0.010)\end{array}$ & $\begin{array}{c}0.022 * * \\
(0.008)\end{array}$ & $\begin{array}{c}0.021 * * \\
(0.009)\end{array}$ & $\begin{array}{c}0.018^{* * *} * \\
(0.005)\end{array}$ & $\begin{array}{c}0.015^{* * *} \\
(0.005)\end{array}$ & $\begin{array}{c}0.011 * * * \\
(0.003)\end{array}$ \\
\hline Constant & $\begin{array}{c}-3.681 * * * \\
(0.561)\end{array}$ & $\begin{array}{c}-3.256^{* * *} \\
(0.345)\end{array}$ & $\begin{array}{c}-3.504 * * * \\
(0.313)\end{array}$ & $\begin{array}{c}-3.495 * * * \\
(0.214)\end{array}$ & $\begin{array}{c}-3.507 * * * \\
(0.196)\end{array}$ & $\begin{array}{c}-3.648 * * * \\
(0.210)\end{array}$ & $\begin{array}{c}-3.663 * * * \\
(0.222)\end{array}$ \\
\hline
\end{tabular}

Panel B: Chiefly Traded Only on Provincial Markets

\begin{tabular}{lccccccc}
\hline & 1869 & 1879 & 1889 & 1899 & 1909 & 1919 & 1929 \\
\hline \multirow{3}{*}{ HQRestUK } & $6.776^{* * *}$ & $6.070^{* * *}$ & $5.835^{* * *}$ & $5.766^{* * *}$ & $5.216^{* * *}$ & $5.256^{* * *}$ & $4.696^{* * *}$ \\
& $(0.548)$ & $(0.370)$ & $(0.309)$ & $(0.309)$ & $(0.271)$ & $(0.305)$ & $(0.338)$ \\
IndTransport & $1.392^{* *}$ & $0.945^{* *}$ & $0.722^{* *}$ & $0.728^{* *}$ & $0.621^{* *}$ & $0.556^{*}$ & 0.399 \\
& $(0.564)$ & $(0.395)$ & $(0.324)$ & $(0.285)$ & $(0.285)$ & $(0.324)$ & $(0.381)$ \\
IndFinancial & $0.923 *$ & 0.357 & $1.284 * * *$ & $1.442^{* * *}$ & $1.295^{* * *}$ & $1.231^{* * *}$ & $1.225^{* * *}$ \\
& $(0.480)$ & $(0.344)$ & $(0.320)$ & $(0.285)$ & $(0.249)$ & $(0.280)$ & $(0.293)$ \\
MarketCap & $-0.372^{* * *}$ & $-0.239^{* * *}$ & $-0.197 * *$ & $-0.072^{* *}$ & $-0.078^{* *}$ & $-0.110^{* * *}$ & -0.051 \\
& $(0.140)$ & $(0.092)$ & $(0.094)$ & $(0.034)$ & $(0.032)$ & $(0.034)$ & $(0.033)$ \\
Constant & $-4.521^{* * *}$ & $-3.735^{* * *}$ & $-3.970^{* * *}$ & $-4.303 * * *$ & $-4.106^{* * *}$ & $-4.257 * * *$ & $-4.636^{* * *}$ \\
& $(0.629)$ & $(0.409)$ & $(0.334)$ & $(0.327)$ & $(0.282)$ & $(0.312)$ & $(0.351)$ \\
& & & & & & & \\
\hline Pseudo R ${ }^{2}$ & 0.540 & 0.511 & 0.497 & 0.469 & 0.427 & 0.418 & 0.356 \\
Observations & 598 & 875 & 1,130 & 1,458 & 1,614 & 1,488 & 1,445 \\
\hline \hline
\end{tabular}

Notes: Multinomial logit analysis with listing strategies as the dependent variable, with the following specification:

$$
\text { ListingType }=\beta_{0}+\beta_{1}(\text { HQRestUK })+\beta_{2}(\text { IndTransport })+\beta_{3}(\text { IndFinancial })+\beta_{4}(\text { MarketCap })
$$

'London Only' is the base ListingType group. Robust standard errors are in parentheses. *** $\mathrm{p}<0.01 ; * * \mathrm{p}<0.05$;

$* \mathrm{p}<0.1$. When companies had multiple securities the returns and liquidity are averaged across securities.

Definitions of variables provided in Appendix Table 1. 
TABLE 6

AVERAGE LIQUIDITY ON EACH MARKET BY DECADE

\begin{tabular}{lccccccc}
\hline \hline & $1869-$ & $1880-$ & $1890-$ & $1900-$ & $1910-$ & $1920-$ & $1869-$ \\
& 1879 & 1889 & 1899 & 1909 & 1919 & 1929 & 1929 \\
\hline UK and Ireland & 0.53 & 0.52 & 0.52 & 0.49 & 0.50 & 0.50 & 0.51 \\
London & 0.53 & 0.52 & 0.52 & 0.48 & 0.50 & 0.50 & 0.50 \\
Provincial & 0.56 & 0.54 & 0.56 & 0.52 & 0.51 & 0.48 & 0.53 \\
\hline Listing Strategy & & & & & & & \\
London Only & 0.49 & 0.50 & 0.50 & 0.47 & 0.50 & 0.50 & 0.49 \\
London \& Provincial & 0.60 & 0.59 & 0.57 & 0.53 & 0.51 & 0.49 & 0.55 \\
Provincial Only & 0.53 & 0.51 & 0.55 & 0.51 & 0.51 & 0.48 & 0.52 \\
\hline Provincial Markets & & & & & & & \\
Birmingham & 0.52 & 0.47 & 0.59 & 0.55 & 0.56 & 0.41 & 0.52 \\
Edinburgh & 0.67 & 0.61 & 0.58 & 0.55 & 0.55 & 0.54 & 0.58 \\
Glasgow & 0.67 & 0.62 & 0.59 & 0.54 & 0.56 & 0.53 & 0.59 \\
Liverpool & 0.60 & 0.60 & 0.58 & 0.55 & 0.54 & 0.53 & 0.57 \\
Manchester & 0.58 & 0.60 & 0.58 & 0.55 & 0.53 & 0.50 & 0.56 \\
Other Minor Markets & 0.53 & 0.51 & 0.55 & 0.49 & 0.48 & 0.48 & 0.51 \\
\hline
\end{tabular}

Notes: Liquidity was measured as the proportion of securities in the Investor's Monthly Manual which traded in a particular month, and this was estimated by looking at the proportion whose price changed.

Source: Authors' calculations based on data from Investor's Monthly Manual. 
TABLE 7

REGRESSIONS EXPLAINING LIQUIDITY

\begin{tabular}{|c|c|c|c|c|c|c|}
\hline & 1879 & 1889 & 1899 & 1909 & 1919 & 1929 \\
\hline London\&Provincial & $\begin{array}{c}0.131 * * * \\
(0.029)\end{array}$ & $\begin{array}{c}0.064 * * \\
(0.026)\end{array}$ & $\begin{array}{c}0.048 * * \\
(0.019)\end{array}$ & $\begin{array}{c}0.039 * * \\
(0.016)\end{array}$ & $\begin{array}{c}0.017 \\
(0.016)\end{array}$ & $\begin{array}{l}-0.027 \\
(0.017)\end{array}$ \\
\hline ProvincialOnly & $\begin{array}{l}0.055^{*} \\
(0.033)\end{array}$ & $\begin{array}{l}-0.008 \\
(0.026)\end{array}$ & $\begin{array}{c}0.093 * * * \\
(0.018)\end{array}$ & $\begin{array}{c}0.095^{* * * *} \\
(0.016)\end{array}$ & $\begin{array}{c}0.092 * * * \\
(0.020)\end{array}$ & $\begin{array}{c}0.018 \\
(0.020)\end{array}$ \\
\hline HQRestUK & $\begin{array}{c}0.014 \\
(0.031)\end{array}$ & $\begin{array}{c}0.026 \\
(0.025)\end{array}$ & $\begin{array}{c}-0.043 * * * \\
(0.016)\end{array}$ & $\begin{array}{c}-0.072 * * * \\
(0.014)\end{array}$ & $\begin{array}{c}-0.062 * * * \\
(0.016)\end{array}$ & $\begin{array}{c}-0.081 * * * \\
(0.015)\end{array}$ \\
\hline IndTransport & $\begin{array}{c}0.005 \\
(0.021)\end{array}$ & $\begin{array}{c}0.001 \\
(0.016)\end{array}$ & $\begin{array}{c}-0.004 \\
(0.012)\end{array}$ & $\begin{array}{l}-0.010 \\
(0.012)\end{array}$ & $\begin{array}{c}-0.016 \\
(0.012)\end{array}$ & $\begin{array}{c}-0.039 * * * \\
(0.013)\end{array}$ \\
\hline IndFinancial & $\begin{array}{c}0.020 \\
(0.019)\end{array}$ & $\begin{array}{l}-0.014 \\
(0.016)\end{array}$ & $\begin{array}{l}-0.014 \\
(0.013)\end{array}$ & $\begin{array}{c}0.011 \\
(0.013)\end{array}$ & $\begin{array}{l}-0.006 \\
(0.013)\end{array}$ & $\begin{array}{c}-0.026^{*} \\
(0.013)\end{array}$ \\
\hline MarketCap & $\begin{array}{c}0.000 \\
(0.001)\end{array}$ & $\begin{array}{c}0.002 * * * \\
(0.001)\end{array}$ & $\begin{array}{c}0.002 * * * \\
(0.001)\end{array}$ & $\begin{array}{c}0.003 * * * \\
(0.000)\end{array}$ & $\begin{array}{c}0.003 * * * \\
(0.001)\end{array}$ & $\begin{array}{c}0.002 * * * \\
(0.000)\end{array}$ \\
\hline Constant & $\begin{array}{c}0.492 * * * \\
(0.016)\end{array}$ & $\begin{array}{c}0.525 * * * \\
(0.012)\end{array}$ & $\begin{array}{c}0.515 * * * \\
(0.008)\end{array}$ & $\begin{array}{c}0.496 * * * \\
(0.008)\end{array}$ & $\begin{array}{c}0.505^{* * *} * \\
(0.008)\end{array}$ & $\begin{array}{c}0.547 * * * \\
(0.008)\end{array}$ \\
\hline $\begin{array}{l}\text { Observations } \\
\text { R-squared }\end{array}$ & $\begin{array}{c}881 \\
0.037\end{array}$ & $\begin{array}{l}1,140 \\
0.022\end{array}$ & $\begin{array}{l}1,469 \\
0.036\end{array}$ & $\begin{array}{l}1,621 \\
0.044\end{array}$ & $\begin{array}{l}1,493 \\
0.053\end{array}$ & $\begin{array}{l}1,449 \\
0.066\end{array}$ \\
\hline
\end{tabular}

Notes: Robust standard errors are in parentheses. $* * * \mathrm{p}<0.01 ; * * \mathrm{p}<0.05 ; * \mathrm{p}<0.1$.Definitions of variables provided in Appendix Table 1. Ordinary least squares regressions, where the dependent variable is the proportion of months that the securities of a company traded over the past 10 years, with the following specification:

Liquidity $=\beta_{0}+\beta_{1}($ London\&Provincial $)+\beta_{2}($ ProvincialOnly $)+\beta_{3}($ HQRestUK $)+\beta_{4}($ IndTransport $)+\beta_{5}($ IndFinancial $)+\beta_{6}($ MarketCap $)$ 
TABLE 8

AVERAGE NUMBER OF GOVERNANCE PROVISIONS OF COMPANIES ON LONDON VS PROVINCIAL MARKETS

\begin{tabular}{lcccc}
\hline \hline & Maximum & $\begin{array}{c}\text { London } \\
\text { Only }\end{array}$ & $\begin{array}{c}\text { London \& } \\
\text { Provincial }\end{array}$ & $\begin{array}{c}\text { Provincial } \\
\text { Only }\end{array}$ \\
\hline SPI Total & 18 & 8.1 & & \\
Default 1862 & 11 & 6.1 & 6.5 & 8.4 \\
LSE 1902 & 6 & 3.8 & 3.7 & 6.7 \\
Observations & & 189 & 26 & 131 \\
& & & & \\
\hline \hline
\end{tabular}

Notes: 'SPI Total' refers to all 18 governance provisions examined by Acheson et al. (2019). These included whether Accounts were audited, Accounts were mailed before the AGM, Access to company books, the Auditor was a shareholder, $10 \%$ or less of capital was needed for an EGM, Proxy voting, 5 or less shareholders required to force poll, Graduated voting scheme, Upper limit on votes, More than one AGM, Preemptive rights on new share issues, Limits on directors' borrowing powers, Director cannot vote if any conflict of interest, Director cannot profit directly from contracts, Ban on repurchases, No approval of transfer, Transfer books not closed, Capital loss triggers AGM to liquidate 'Default 1862' refers to the subset of 11 provisions which were recommended by the government in the Table A appendix to the 1862 Companies Act. 'LSE 1902' refers to the subset of 6 governance provisions which would normally be expected of companies listing on the London Stock Exchange according to Gore-Brown (1902). Further details of these variables are given in Appendix Table 1. Source: Data from Acheson et al. (2019). 
TABLE 9

REGRESSIONS EXPLAINING GOVERNANCE PROVISIONS

(1)

SPITotal
(2)

Default 1862
(3)

LSE1902

$\begin{array}{lccc}\text { London\&Provincial } & 0.157 & 0.396 & -0.020 \\ & (0.511) & (0.534) & (0.405) \\ \text { ProvincialOnly } & 0.268 & 0.638 & -0.092 \\ & (0.396) & (0.394) & (0.268) \\ \text { HQRestUK } & 0.037 & -0.030 & -0.303 \\ & (0.375) & (0.376) & (0.262) \\ \text { IndTransport } & -0.059 & -0.055 & -0.013 \\ & (0.372) & (0.338) & (0.282) \\ \text { IndFinancial } & 0.021 & -0.548^{* *} & -0.354^{*} \\ & (0.259) & (0.234) & (0.184) \\ \text { MarketCap } & 0.228 & -0.074 & 0.512^{* * *} \\ & (0.239) & (0.188) & (0.187) \\ \text { Constant } & 8.045^{* * *} & 6.286^{* * *} & 3.752^{* * *} \\ & (0.185) & (0.155) & (0.157) \\ \text { Observations } & & & 335 \\ \text { R-squared } & 335 & 335 & 0.055\end{array}$

Notes: Robust standard errors are in parentheses. $* * * \mathrm{p}<0.01 ; * * \mathrm{p}<0.05 ; * \mathrm{p}<0.1$.Definitions of variables provided in Appendix Table 1. Ordinary least squares regressions, where the dependent variable is the number of shareholder protection provisions which were adopted by a company, with the following specification:

Shareholder Protections

$$
\begin{aligned}
& =\beta_{0}+\beta_{1}(\text { London\&Provincial })+\beta_{2}(\text { ProvincialOnly })+\beta_{3}(\text { HQRestUK }) \\
& +\beta_{4}(\text { IndTransport })+\beta_{5}(\text { IndFinancial })+\beta_{6}(\text { MarketCap })
\end{aligned}
$$




\section{APPENDIX TABLE 1 \\ DEFINITIONS OF VARIABLES}

\begin{tabular}{|c|c|}
\hline Variable & Definition \\
\hline London\& & Dummy variable which equals 1 if the company was jointly traded on \\
\hline Provincial & London and Provincial markets \\
\hline ProvincialOnly & $\begin{array}{l}\text { Dummy variable which equals } 1 \text { if the company was traded only on } \\
\text { provincial markets }\end{array}$ \\
\hline HQRestUK & $\begin{array}{l}\text { Dummy variable which equals } 1 \text { if the company had its headquarters in the } \\
\text { UK, but outside London }\end{array}$ \\
\hline IndTransport & $\begin{array}{l}\text { Dummy variable which equals } 1 \text { if the company operated in the transport } \\
\text { sector, namely railways, canals, docks, and shipping firms. }\end{array}$ \\
\hline IndFinancial & $\begin{array}{l}\text { Dummy variable which equals } 1 \text { if the company operated in the financial } \\
\text { sector, namely banks, insurance, land, mortgage and finance firms, and } \\
\text { investment trusts. }\end{array}$ \\
\hline MarketCap & $\begin{array}{l}\text { The market capitalization (price * number of securities outstanding) for the } \\
\text { company. This is aggregated across all security types, including ordinary } \\
\text { shares, preference shares and bonds listed in the IMM. }\end{array}$ \\
\hline SPITotal & $\begin{array}{l}\text { Of the } 18 \text { provisions in the Shareholder Protection Index (SPI) of Acheson et } \\
\text { al. (2019), the total number of these provisions which were adopted by a } \\
\text { company. These included whether Accounts were audited, Accounts were } \\
\text { mailed before the AGM, Access to company books, the Auditor was a } \\
\text { shareholder, } 10 \% \text {, or less, of capital was needed for an EGM, Proxy voting, } 5 \\
\text { or less shareholders required to force poll, Graduated voting scheme, Upper } \\
\text { limit on votes, More than one AGM, Preemptive rights on new share issues, } \\
\text { Limits on directors' borrowing powers, Director cannot vote if any conflict } \\
\text { of interest, Director cannot profit directly from contracts, Ban on } \\
\text { repurchases, No approval of share transfer, Transfer books not closed, } \\
\text { Capital loss triggers AGM to liquidate. }\end{array}$ \\
\hline
\end{tabular}

Default1862 Of the 11 SPI provisions in Table A 1862, the total number of these provisions which were adopted by a company. These included whether Accounts were audited, Accounts were mailed before the AGM, Access to company books, $10 \%$ or less of capital was needed for an EGM, Proxy voting, 5 or less shareholders to force poll, Graduated voting, Preemptive rights on new share issues, Director cannot vote if any conflict, Director cannot profit directly from contracts, No approval of share transfer.

LSE1902

Of the 6 SPI provisions required by the London Stock Exchange in 1902, the total number of these provisions which were adopted by a company. These included whether Accounts were mailed before the AGM, $10 \%$ or less of capital needed for EGM, Limits on directors' borrowing powers, Director cannot vote if any conflict of interest, Ban on repurchases, No approval of share transfer. 